\title{
Niosome Encapsulated Bromelain Reduced IL-6 and TNF- $\alpha$ in LPS Induced Human Skin Fibroblast Cell Line
}

\author{
Siavash Hosseinpour Chermahini ${ }^{1,2 *}$, Fadzilah Adibah Abdul Majid ${ }^{1}$, Azila Abdul Aziz ${ }^{1}$ and Roya Anvari ${ }^{2}$ \\ ${ }^{1}$ Department of Bioprocess Engineering, Faculty of Chemical Engineering, Universiti Teknologi, Malaysia, 81310 Johor Bahru, Johor, Malaysia. \\ ${ }^{2}$ The University of Georgia, Kostava St. 77a, 0171 Tbilisi, Georgia.
}

*Corresponding Author: Siavash Hosseinpour Chermahini, Department of Bioprocess Engineering, Faculty of Chemical Engineering, Universiti Teknologi, Malaysia, 81310 Johor Bahru, Johor, Malaysia.

Received date: May 16, 2021; Accepted date: July 13, 2021; Published date: August 20, 2021

Citation: Siavash H. Chermahini, Fadzilah A. A. Majid, Azila A. Aziz and Anvari R., (2021) The tower of Babylon - bioreactor. J, Biotechnology and Bioprocessing 2(7); DOI: 10.31579/2766-2314/044

Copyright: (C) 2021, Siavash Hosseinpour Chermahini, This is an open access article distributed under the Creative Commons Attribution License, which permits unrestricted use, distribution, and reproduction in any medium, provided the original work is properly cited.

\begin{abstract}
The topical delivery of bromelain as an anti-inflammatory solution for skin inflammation has attracted the attention of researchers. Due to the skin barrier issue, a new method was designed for the effective delivery of specific doses of bromelain to the desired action sites. A niosome was selected as a novel and practical transdermal vehicle for the delivery of bromelain to inflamed sites. In this regard, a lipopolysaccharide (LPS)-induced human skin fibroblast (HSF1184) cell line was assembled in-vitro as a simulated model. The levels of interleukin-6 (IL-6) and tumour necrosis factor alpha (TNF- $\alpha$ ), the two immune-modulatory regulators of cell responses to inflammation, were measured to determine the response towards the niosome-encapsulated bromelain treatment. The results showed that the niosome-encapsulated bromelain significantly reduced the levels of IL- 6 and TNF- $\alpha$ compared to the nonencapsulated bromelain, the vehicle (niosome) and the control.
\end{abstract}

Keyword: niosome, human skin fibroblast, inflammation, IL-6, TNF- $\alpha$, bromelain

\section{Introduction}

Bromelain has demonstrated many beneficial properties in-vitro and invivo such as anti-oedematous, anti-thrombotic, and fibrinolytic properties. Most importantly, clinical trials of bromelain have confirmed its antiinflammatory properties, which include, but are not limited to, breast engorgement during lactation [1]; osteoarthritis of the knee and hip [2, 3]; rhinosinusitis [4]; sepsis in children [5]; and urogenital inflammation [6]. Experimental evidence also exists on its effects on blood coagulation, where increases in the serum fibrinolytic activity and prostaglandin levels have been recorded due to a decrease in PGE2 and thromboxane A2. Essentially, this phenomenon is important for reducing inflammation [7]. However, there are many internal and external factors that trigger the transcription of pro-inflammatory cytokines in the human body, for instance, viral and bacterial infections, cuts, wounds, and obesity. Bromelain inhibits bacterial endotoxin LPS-induced NF-kB activity as well as the expression of PGE2 and Cox-2 [8]. To explain this mechanism, it was hypothesized that bromelain induces the cleavage of cell surface markers such as CD14 [9]. Among the secreted regulators of inflammation that are connected to the NF-kB pathways and that respond to bromelain are IFN- $\gamma$, TNF- $\alpha$, IL- $1 \beta$, and IL-6. Depending on the context and micro-environment, these regulators can either stimulate tumour growth and invasion or activate immune responses and cause tumour regression [10-13]. Experimental evidence derived from an analysis of peripheral blood mononuclear cells (PBMC) from healthy volunteers as well as mouse macrophages suggest that bromelain can activate TNF- $\alpha$, IL-1 $\beta$ and IL-6 secretions in an IFN- $\gamma$-dependent mechanism $[14,15]$. However, the IFN- $\gamma$ production is also encouraged by the presence of bromelain [16]. These data led to the hypothesis that bromelain has the potential to activate a healthy immune system to ensure a rapid response to pathogens and cellular stress. Nevertheless, in situations when immune cells have already been stimulated, bromelain reduces the secretion of TNF- $\alpha$ and IL-6 [17]. According to the summary by Chobotova et al. (2010) [18] on the influence of bromelain on inflammation regulation in relation to the cancer network, an overproduction of cytokines is expected in inflammation-induced cases. A study has also found that in the presence of LPS, which can stimulate an acute inflammatory reaction, bromelain reduces elevated TNF- $\alpha$, IL- $1 \beta$, and IL-6 expressions in human PBMC [19]. The reduction of TNF- $\alpha$ and IFN- $\gamma$ expressions has also been observed in inflamed tissues of patients with inflammatory bowel disease (IBD) that have been treated with bromelain [20]. The described data demonstrate that the effects of bromelain on cytokine expressions depend on the presence of inflammation-inducing conditions. This underlines the potential of bromelain for the treatment of inflammation-based pathologies. However, the challenge of the transdermal therapeutic system (TTS) is the stratum corneum (SC). The stratum corneum (SC) is the main barrier to the transportation of nutritional compounds via the skin [21]. In this regard, 
the delivery and release of bioactive materials like bromelain to different parts of the body are practically controlled by nanocarriers [22]. Several types of nanocarrier systems are available for TTSs such as vesicular phospholipid gels (VPG) [23], microspheres [24], nanospheres [25], nanoliposomes [26] liposomes [27] archaeosomes [28], complexes [29], ethosomes [30], dendrimers [31] nanoemulsions [32], and niosomes [33]. The effective delivery of bromelain to the affected sites depends on the delivery system used in the topical formulation [34]. Niosomes have specific characteristics for topical delivery [35] as theypossess high chemical long-term stability; high solubility for lipophilic and hydrophilic components; complete drug delivery; and large membrane flexibility to be effective against the SC barrier [36]. Niosomes are thermodynamically stable because they contain two volumes of liquids, namely water and oil, which are combined into a single phase by means of a surfactant to produce a non-ionic surfactant. Moreover, niosomes are highly compatible with biological systems and have no toxicity because of their non-ionic nature [37]. Due to the technological and physicochemical characteristics of niosomes, researchers have been motivated to consider them as ideal for carrying drugs for topical administration [38, 39]. For instance, Bouwstra and Hofland (1996) [40] loaded ellagic acid (EA) onto a niosome as an antioxidant drug application by transdermal administration. LPS is a suitable agent in stimulating inflammation since it can be used to induce inflammation both in-vitro and in-vivo. [41]. In order to detect LPS-induced inflammation, 2 cytokines, namely IL- 6 and TNF- $\alpha$, were selected in this study. IL-6 and TNF- $\alpha$ are immunomodulating agents that act as regulators of host responses to infection, immune responses, inflammation, and trauma. They include various groups of soluble proteins, peptides, or glycoproteins which act as hormonal regulators or signalling molecules from nanomolar to picomolar concentrations [42]. Some of them are pro-inflammatory, being necessary for initiating the inflammatory response that is needed for the recruitment of granulocytes and, later on, lymphocytes, to fight disease. However, excessive inflammation is sometimes the pathogenicity of certain diseases. Other cytokines are anti-inflammatory and serve to reduce inflammation and promote healing [43]. Essentially, the definition of inflammation is that the cells are alive up to a certain point but will die subsequently. In this study, niosome-encapsulated bromelain was shown to be an effective compound that reduces the levels of IL- 6 and TNF- $\alpha$ in LPS-induced inflammation of the human skin fibroblast (HSF1184) cell line. This is the first study to use niosome-encapsulated bromelain as an anti-inflammatory application. In order to determine the effectiveness of the treatment in HSF1184, the LPS-induced inflammation was treated with niosome-encapsulated bromelain after four hours of induction. The inflammation responses were measured after four hours and 24hours.

\section{Materials and Methods}

\subsection{Chemicals and Cell Culture}

All the chemicals used in this study were purchased from Sigma Aldrich and Merck, unless noted otherwise. These included Span $(40,60,80)$, Labrasol, dicetyl phosphate, chloroform, DMEM, trypsin, penicillin, streptomycin, MTT solution, and DMSO (sterile and non-sterile). The bromelain was purchased from Merck, while the LPS from Escherichia coli (0111:B4) was purchased from Sigma Aldrich. The TNF-a kit (Catalogue Number RAB0476) and IL-6 kit (Catalogue Number RAB0307) were purchased from Sigma Aldrich (USA). Acetaminophen tablets $(80 \mathrm{mg})$ were purchased from Guardian Pharmacy. HSF1184 was purchased from ATCC (USA) (Catalogue No. 107-75a). The cell culture grade chemicals and analytical grade chemicals used in this study were from Sigma Aldrich.

\subsection{Preparation of Niosome-Encapsulated Bromelain}

The niosome was created based on the protocol of Arora and Sharma (2010) [44] with minor modifications. First of all, a mixture of the vesicleforming agents, i.e., the surfactant $(40,60,80)$ and Labrasol, was dissolved in chloroform (a volatile organic solvent) in a round-bottom flask at a mole ratio of 1:1. The organic solvent was removed at a temperature of $45^{\circ} \mathrm{C}$ using a rotary evaporator $(40 \mathrm{rpm})$, leaving a thin film of solid mixture deposited on the wall of the flask. This dried surfactant film was then rehydrated with $100 \mathrm{~mL}$ of aqueous-phase distilled water and was then agitated gently for an hour to yield multi-lamellar niosomes. The mixture was subjected to probe sonication using a Fisher Scientific sonicator at an amplitude of $40 \mathrm{~m}$, energy of $2000 \mathrm{~J}$, and power of $30 \mathrm{~W}$ for two minutes to yield uniform nanoparticles of niosomes. After selecting a span of $60(40,60,80)$, different concentrations of bromelain $(10,30,50,70,90)$ with different ratios of span/labrasol $(50 / 50,60 / 40$, $70 / 30)$ were tested in this study.

\begin{tabular}{|c|c|c|c|c|c|c|c|}
\hline NO. & Surfactant & $\begin{array}{l}\text { Span } \\
\text { (mg) }\end{array}$ & $\begin{array}{c}\text { Bromelain( } \\
\text { mg) }\end{array}$ & $\begin{array}{c}\text { Labrasol( } \\
\mathrm{mL})\end{array}$ & $\begin{array}{l}\text { Dicetyl } \\
\text { Phosphate } \\
\text { (mg) }\end{array}$ & $\begin{array}{c}\text { Chlorofo } \\
\text { rm } \\
(\mathrm{mL})\end{array}$ & $\begin{array}{c}\text { Distilled } \\
\text { Water } \\
(\mathrm{mL})\end{array}$ \\
\hline 1 & \multirow{5}{*}{$\begin{array}{c}\text { Span 60/Labrasol } \\
(50 / 50)\end{array}$} & \multirow{5}{*}{47.5} & 10 & \multirow{5}{*}{47.5} & \multirow{5}{*}{5} & \multirow{5}{*}{100} & \multirow{5}{*}{100} \\
\hline 2 & & & 30 & & & & \\
\hline 3 & & & 50 & & & & \\
\hline 4 & & & 70 & & & & \\
\hline 5 & & & 90 & & & & \\
\hline 6 & \multirow{5}{*}{$\begin{array}{c}\text { Span 60/Labrasol } \\
(60 / 40)\end{array}$} & \multirow{5}{*}{57.5} & 10 & \multirow{5}{*}{37.5} & \multirow{5}{*}{5} & \multirow{5}{*}{100} & \multirow{5}{*}{100} \\
\hline 7 & & & 30 & & & & \\
\hline 8 & & & 50 & & & & \\
\hline 9 & & & 70 & & & & \\
\hline 10 & & & 90 & & & & \\
\hline 11 & \multirow{5}{*}{$\begin{array}{c}\text { Span 60/Labrasol } \\
(70 / 30)\end{array}$} & \multirow{5}{*}{67.5} & 10 & \multirow{5}{*}{27.5} & \multirow{5}{*}{5} & \multirow{5}{*}{100} & \multirow{5}{*}{100} \\
\hline 12 & & & 30 & & & & \\
\hline 13 & & & 50 & & & & \\
\hline 14 & & & 70 & & & & \\
\hline 15 & & & 90 & & & & \\
\hline
\end{tabular}




\subsection{Cell Line Culture and Maintenance}

The cell culture and maintenance followed the protocol of Freshney (2008) [45]. The cells were cultured between passages 7 and 9. A water bath at $37^{\circ \mathrm{C}}$ was used to pre-warm all the media and solutions before use. The cells were maintained routinely in a $75-\mathrm{cm}^{2}$ flask. Moreover, the cells that had been cultured in Dulbecco's modified Eagle's medium (DMEM) containing penicillin (100 units/ml), streptomycin $(100 \mathrm{lg} / \mathrm{ml})$, and foetal bovine serum $(10 \% \mathrm{v} / \mathrm{v})$ were also incubated in a humidified incubator with $5 \% \mathrm{CO}_{2} / 95 \%$ air at $37^{\circ} \mathrm{C}$. The cells took between $24-48$ hours to reach a confluent state. Cells from the exponential growth phase were used for the experimental work, where $2 \times 10^{5} \mathrm{cells} / \mathrm{mL}$ were loaded into each well and incubated for 24 hours for cell attachment before the start of the experiment.

\subsection{Inflammation Induction of HSF1184 with Serial Dilution of LPS}

The serial dilution of LPS was modified from the protocol of Freshney (2008) [45]. After mixing $1 \mathrm{mg}$ of LPS with $1 \mathrm{~mL}$ of deionized water (DIW) according to the manufacturer's instructions (stock LPS solution), serial dilutions of LPS were performed from $12 \mu \mathrm{g} / \mathrm{mL}$ to $1.5 \mu \mathrm{g} / \mathrm{mL}(1.5$ $\mu \mathrm{g} / \mathrm{mL}, 3 \mu \mathrm{g} / \mathrm{mL}, 4.5 \mu \mathrm{g} / \mathrm{mL}, 6 \mu \mathrm{g} / \mathrm{mL}, 7.5 \mu \mathrm{g} / \mathrm{mL}, 9 \mu \mathrm{g} / \mathrm{mL}, 10.5 \mu \mathrm{g} / \mathrm{mL}$, and $12 \mu \mathrm{g} / \mathrm{mL}$ ) by diluting the solution in an appropriate volume of DMEM.

\begin{tabular}{|l|l|l|}
\hline LPSConc. $(\mu \mathrm{g} / \mathrm{ml})$ & LPS $(\mu \mathrm{g})$ & DMEM $(\mu \mathrm{l})$ \\
\hline 1 & 1.5 & 1498.5 \\
\hline 2 & 3 & 1497 \\
\hline 3 & 4.5 & 1495.5 \\
\hline 4 & 6 & 1494 \\
\hline 5 & 7.5 & 1492.5 \\
\hline 6 & 9 & 1491 \\
\hline 7 & 10.5 & 1489.5 \\
\hline 8 & 12 & 1488 \\
\hline
\end{tabular}

Table 2. LPS serial dilution

$200 \mu \mathrm{l}$ of cells at a concentration of $2 \times 10^{5}$ cells/well were seeded in a 96well plate and incubated $\left(5 \% \mathrm{CO}_{2}\right.$ and $\left.37^{\circ} \mathrm{C}\right)$ for two days to reach a confluent state. Then, the cells were exposed to different concentrations of LPS $(1.5,3,4.5,6,7.5,9,10.5,12 \mu \mathrm{g} / \mathrm{mL})$ for four hours or 24 hours using separate plates. The arrangement of the different concentrations of LPS on the plate is presented in Figure 3. DMEM was used as the blank, while cells without the LPS induction were used as the control. The cell induction was terminated accordingly after four hours and 24 hours.

\subsection{Quantification of Cell Viability Using MTT Assay}

The cell viability after the LPS induction was quantified using an MTT assay, as recommended by Freshney (2008) [45]. The assay was used to investigate the effects of niosome-encapsulated bromelain, niosome without bromelain (vehicle), and bromelain alone on the viability of HSF 1184 cells treated with $1.5 \mu \mathrm{g} / \mathrm{mL}$ of LPS-induced inflammation. The HSF1184 cells were seeded at $2-4 \times 10^{4}$ cells per $/ \mathrm{mL}$ on two 96-well plates (4hrs and 24hrs) and were left to grow for two days to a confluent state, with media changes being made once per day. On completion of the confluence cells, inflammation was triggered in the plates treated with 1.5 $\mu \mathrm{l} / \mathrm{mL}$ of LPS and the cells were incubated for four hours at $37^{\circ} \mathrm{C}$ in a humidified atmosphere with $5 \% \mathrm{CO}_{2}$. Then, they were treated with acetaminophen $(2 \mu \mathrm{g} / \mathrm{mL})$, bromelain $(25 \mu \mathrm{g} / \mathrm{mL})$, niosome with $10 \%$ bromelain $(20 \mu \mathrm{l} / \mathrm{mL})$, and niosome as a vehicle $(20 \mu \mathrm{l} / \mathrm{mL})$ before being incubated for either four or 24 hours. The induced cells were washed twice with PBS, and $20 \mu \mathrm{l}$ of MTT solution $(5 \mathrm{mg} / 1 \mathrm{ml}$ PBS$)$ was added to each experimental well. The plate was wrapped with aluminium foil and incubated for four hours. In continue, the MTT solution was carefully removed from all the wells using fine tips before being replaced with $200 \mu \mathrm{l}$ of non-sterile DMSO and mixed well with MTT formazan. A model ELX 808 BIO-TEK plate reader was used to measure the optical density of the colour formations of each sample at a wavelength of $570 \mathrm{~nm}$ and reference wavelength of $630 \mathrm{~nm}$. The procedure for 24 hours was similar to that for four hours. The average of six repetitions taken thrice from each sample was taken as the result. The OD was changed to a percentage of cell viability. Since the control (cells and DMEM) had 100\% viability, the other treatments were compared to the control.

\subsection{Quantification of IL-6 and TNF-a Concentrations}

In accordance with Freshney (2008) [45] protocol, after each culture medium had been collected and centrifuged for three minutes at $3300 \mathrm{rpm}$ and the supernatant had been separated, the resulting cells in the well plates (supernatant) were processed for IL- 6 and TNF- $\alpha$ according to the manufacturer's instructions for the ELISA protocol. The standards and samples were pipette into the wells of the kits. The IL-6 and TNF- $\alpha$ presented in the sample were bound to the wells by the immobilized antibody. The wells were then washed and biotinylated with the added anti-human IL- 6 and TNF- $\alpha$ antibodies. After washing away the unbound biotinylated antibodies, HRP-conjugated streptavidin was pipette into the wells. The wells were again washed before a TMB substrate solution was added to the wells. The colour that developed was in proportion to the amount of IL- 6 and TNF- $\alpha$ that had been bound. The colour of the stop solution changed from blue to yellow. The intensity of the colour was measured at $450 \mathrm{~nm}$, and the result was based on $\mathrm{pg} / \mathrm{mL}$. From the standard curve equation $(\mathrm{y}=\mathrm{a} * \ln (\mathrm{x})+\mathrm{b})$ of both cytokines (IL-6 and TNF- $\alpha$ ), since $\mathrm{y}(\mathrm{OD})=450 \mathrm{~nm}$ and $\mathrm{x}$ is in $\mathrm{pg} / \mathrm{mL}$, then with various amounts of $y$ in the above stated equation, various amounts of $x$ in $\mathrm{pg} / \mathrm{mL}$ were obtained.

\subsection{Treatment of LPS-Induced Inflammation using Niosome-Encapsulated Bromelain}

The LPS induction was carried out according to the protocol by Zdarilova et al. (2009) [46] with minor modifications, as described above. $2-4 \times 10^{4}$ cells $/ \mathrm{mL}$ were prepared at the exponential growth phase, and $200 \mu \mathrm{L}$ of cell suspension was transferred to each well on two 96-well plates according to the plate design. The plates were then incubated in $5 \% \mathrm{CO}_{2}$ 
at $37^{\circ \mathrm{C}}$ for two days with a daily change of medium until the cells reached a confluent state. Then, $1.5 \mu \mathrm{g} / \mathrm{mL}$ of LPS was added to each well and the plates were incubated for another four hours. After four hours of post induction incubation, the designated wells in both the four-hour and 24- hour plates were treated with acetaminophen $(2 \mu \mathrm{g} / \mathrm{mL})$, bromelain $(25 \mu \mathrm{g} / \mathrm{mL})$, niosome with bromelain $10 \%(20 \mu \mathrm{l} / \mathrm{mL})$, and niosome as a vehicle $(20 \mu \mathrm{l} / \mathrm{mL})$, and then incubated again for another four hours or 24 hours.

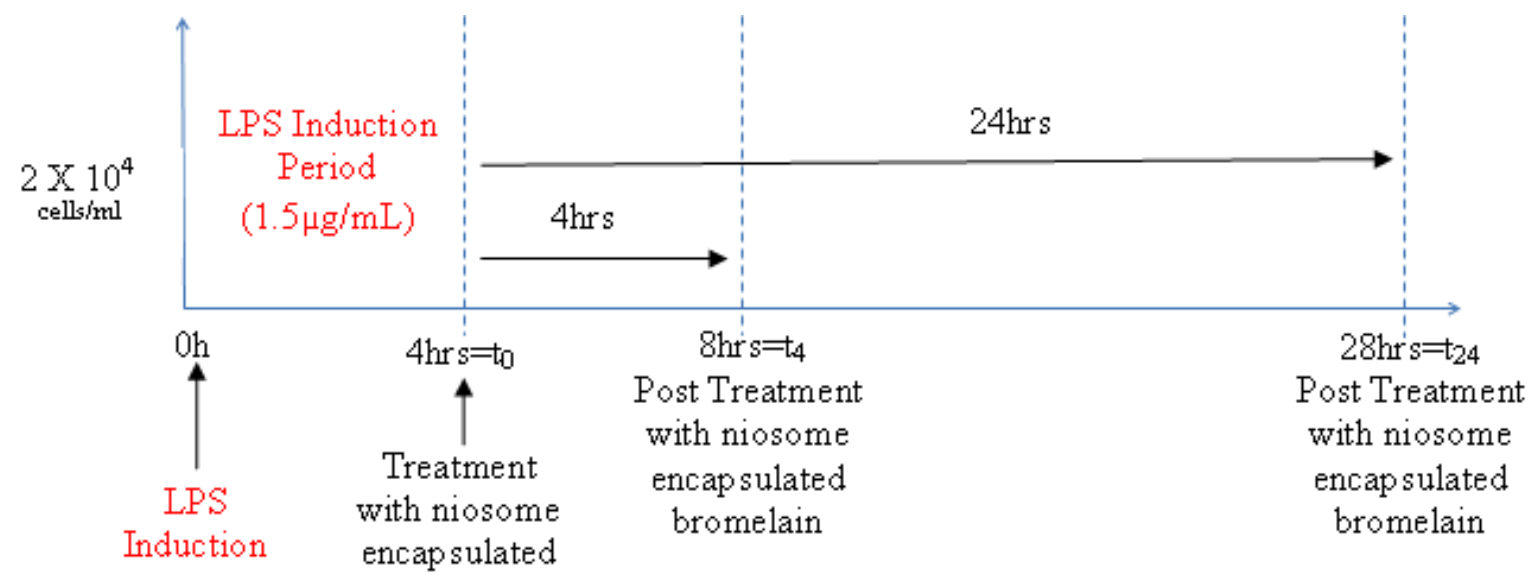

Figure 1. LPS induced inflammation after 4hrs, treated with niosome encapsulated bromelain for 4 hrs and 24 hrs post treatment.

The summary of the LPS induction and treatment with the niosomeencapsulated bromelain for both plates is presented in Figure 1. The cell viability was determined using the MTT assay as described above. The levels of both the IL- 6 and TNF- $\alpha$ cytokines present in the wells were measured accordingly based on the above protocol.

\section{Statistical analysis}

In this experiment, two pairs of samples were compared using the t-Test because these two groups contributed a pair of scores. This statistical technique is often called a paired sample t-test or correlated t-test that tells whether there is a statistically significant difference in the mean scores for niosome-encapsulated bromelain and the other treatments. When $P<0.05$, it means that there is a significant difference.

\section{Results and Discussion}

\subsection{Determination of suitable LPS Concentration to Induce Inflammation in HSF1184}

A suitable concentration of LPS to induce inflammation in HSF1184 was determined based on the cell viability and IL- 6 response. The purpose was to select the lowest concentration of LPS that would cause inflammation on the cells without causing cell death.

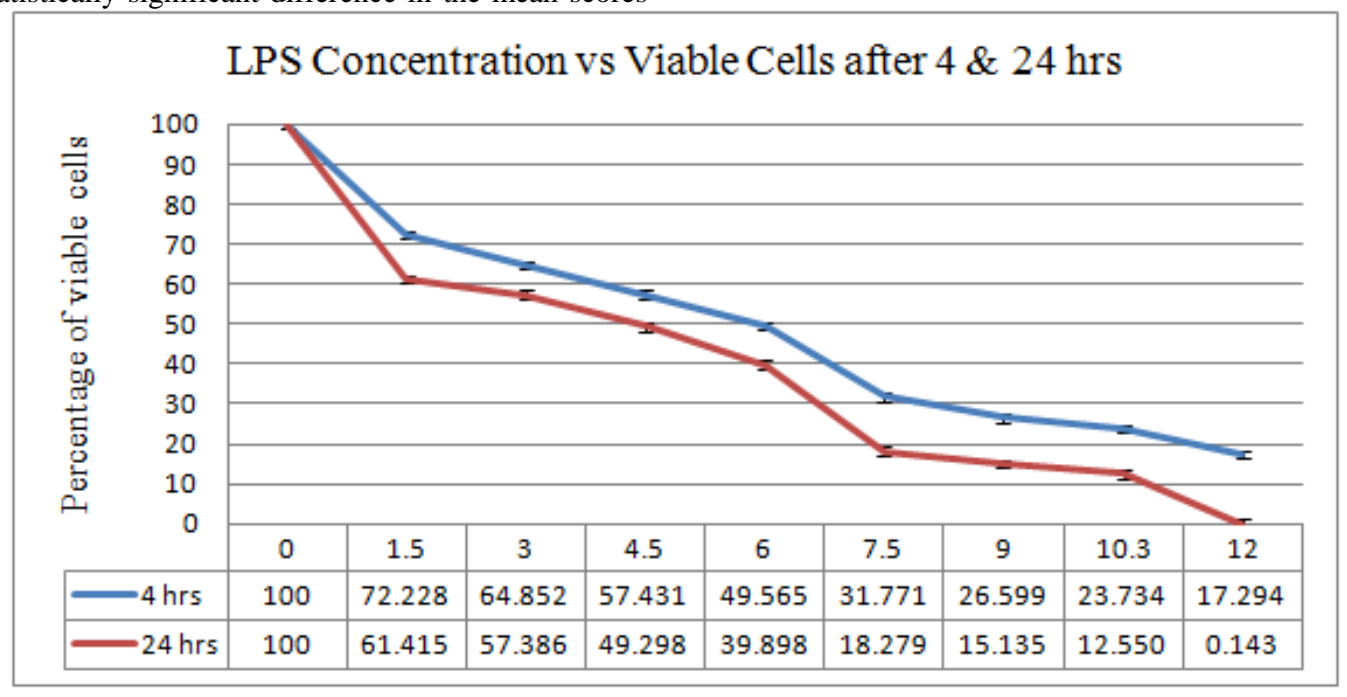

Figure 2. LPS concentration vs viable cells after 4 hrs and 24 hrs.

As shown in Figure 2, the HSF1184 cell line was treated with different concentrations of LPS to induce inflammation after 4 hours and 24 hours. Then, the percentage of viable cells was calculated. By using the paired sample t-Test in the analysis and comparing the LPS concentration of $1.5 \mu \mathrm{g} / \mathrm{mL}$ with other concentrations, the difference was most significant for the $1.5 \mu \mathrm{g} / \mathrm{mL}$ LPS. The interleukin-6 (IL-6) and tumour necrosis factor alpha (TNF- $\alpha$ ) were used as indicators for the host's responses to the inflammation. The suitable concentration of LPS-induced inflammation in the HSF1184 cell line was determined based on the response of the cytokine. The determination of the inflammation-inducing concentration of LPS was based on the production of TNF- $\alpha$ and IL- 6 by the cells. 


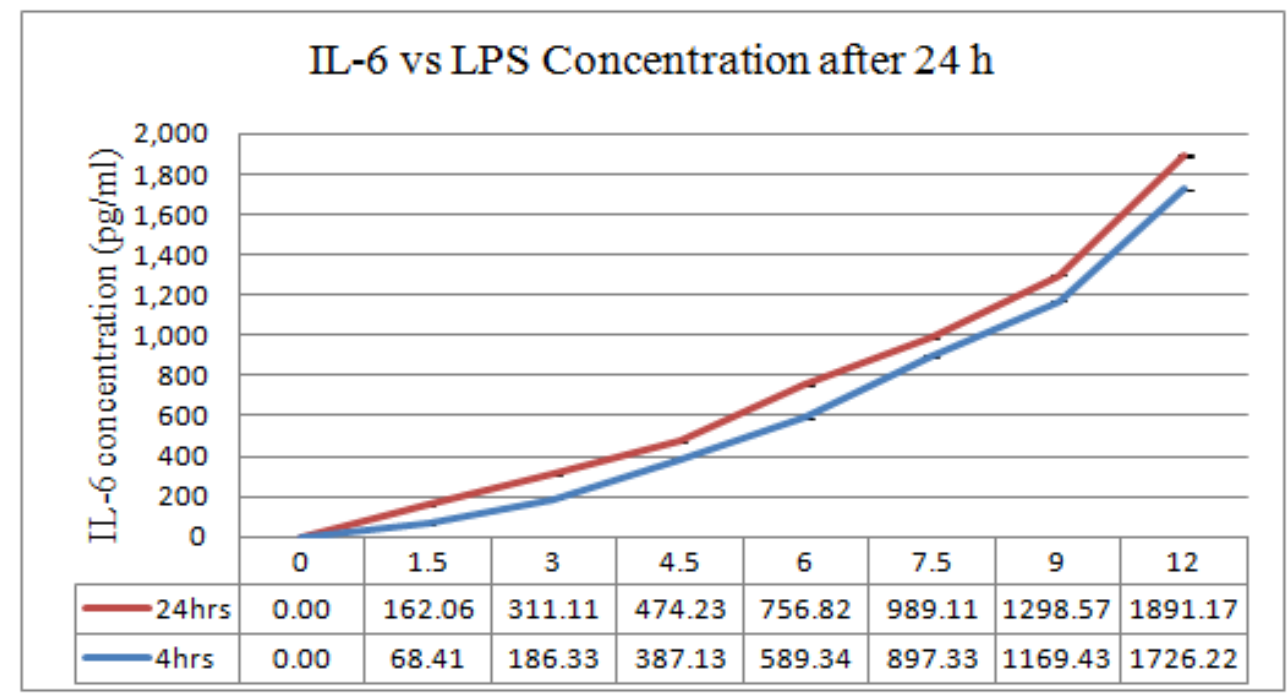

Figure 3. IL-6 Concentration vs LPS concentration after 4 hrs and $24 \mathrm{hrs}$.

In Figure 3, the HSF1184 cell line was treated with different concentrations of LPS-induced inflammation for four hours and 24 hours. The supernatant of the HSF1184 cell line that was inflamed by the LPS was measured by the response of the cytokine (IL-6). By using the paired sample t-Test to compare the concentration of $1.5 \mu \mathrm{g} / \mathrm{mL}$ LPS with other concentrations, the $1.5 \mu \mathrm{g} / \mathrm{mL}$ LPS showed a more significant difference than the other concentrations $(\mathrm{p}<0.05)$. From the two graphs shown above, the suitable concentration of LPS to induce inflammation in the HSF1184 based on the cell viability and the IL-6 response was $1.5 \mu \mathrm{g} / \mathrm{mL}$. Although many different parameters could have been used as the point of reference in this study, the concentration of $1.5 \mu \mathrm{g} / \mathrm{mL}$ had induced inflammation for the MTT assay, IL-6, and TNF- $\alpha$, and thus, their responses toward the HSF1184 cell line were surveyed. Previous studies have found that an effective dose of $1 \mu \mathrm{g} / \mathrm{mL}$ of LPS induced inflammation [47]; however, this study achieved a profound physiological response at $1.5 \mu \mathrm{g} / \mathrm{mL}$. Subsequently, a concentration of $1.5 \mu \mathrm{g} / \mathrm{mL}$ of LPS was used to induce inflammation in the HSF1184 cell line before treatment with niosome as an in-vitro simulated model. This LPS concentration was determined using quantitative experiments such as quantitative cell viability using an MTT assay and quantitative cytokines concentration. Thus, $1.5 \mu \mathrm{g} / \mathrm{mL}$ of LPS was selected to induce inflammation in the HSF1184 cell line in the following experiments.

\subsection{Cell Viability of LPS-Induced HSF1184 Treated with Niosome-Encapsulated Bromelain}

In the MTT assay, inflammation was induced in the HSF1184by the 1.5 $\mu \mathrm{g} / \mathrm{mL}$ LPS. It was treated with the niosome-encapsulated bromelain, non-encapsulated bromelain, and the vehicle (niosome). In this experiment, acetaminophen at a concentration of $2 \mu \mathrm{g} / \mathrm{mL}$ was considered as the positive control, LPS at a concentration of $1.5 \mu \mathrm{g} / \mathrm{mL}$ was the negative control, and DMEM-plus cells with a volume of $1 \mathrm{~mL}$ was the control specimen. The concentrations for the other treatments involving niosome-encapsulated bromelain, bromelain alone, and niosome (vehicle) were $20 \mu \mathrm{g} / \mathrm{mL}, 25 \mu \mathrm{g} / \mathrm{mL}$, and $20 \mu \mathrm{g} / \mathrm{mL}$, respectively, as determined from previous experiments.

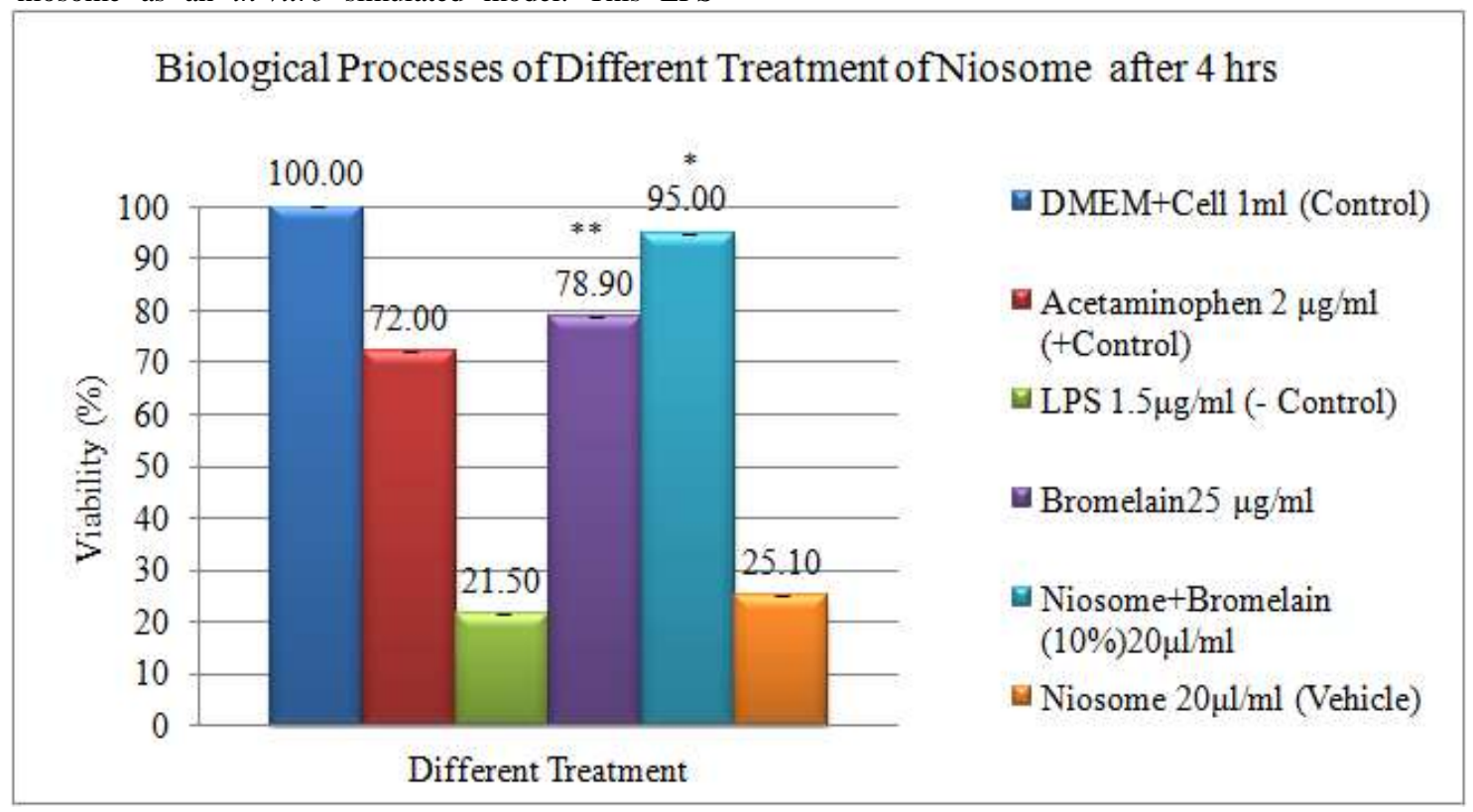

Figure 4. Percentage viability of LPS induced HSF1184 with different treatment after 4 hrs. 


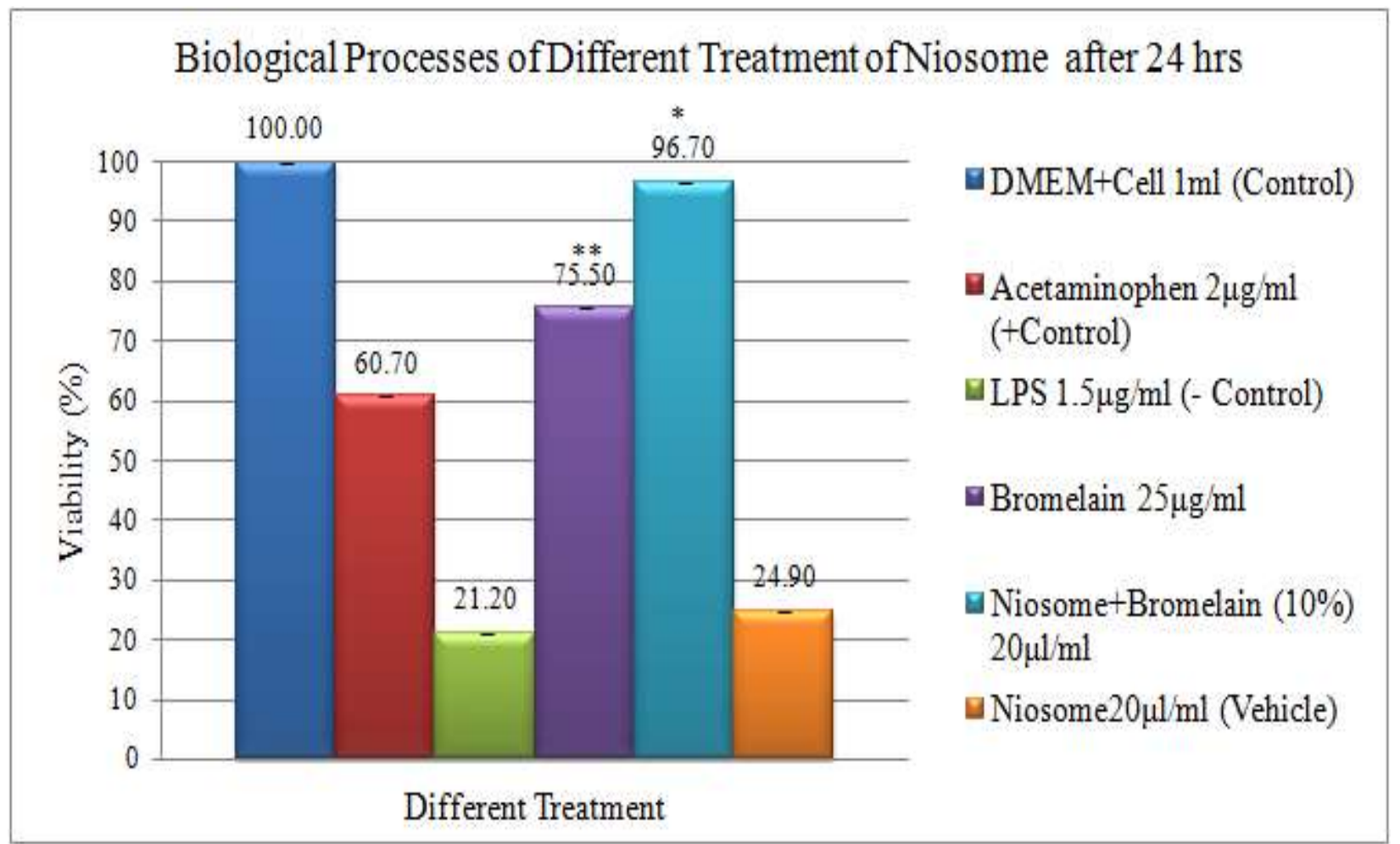

Figure 5. Percentage viability of LPS induced HSF1184 with different treatment after 24 hrs.

Figure 4 and Figure 5 show the differences in the results for various treatments of niosome after four hours and 24 hours. Based on the presented figures, the biggest difference in the percentage of viability was related to the niosome-encapsulated $10 \%$ bromelain, which had a viability of about 96.70 percent in Figure 5 and a viability of 95 percent in Figure 4. On the contrary, the vehicle had the lowest viability at 24.90 percent in Figure 5 and 25.10 percent in Figure 4. However, the viability of bromelain alone was 78.90 percent in Figure 4 and 75.50 percent in Figure 5; this was the second highest after the niosome-encapsulated10\% bromelain (Figure 4 and Figure 5). As a positive control, acetaminophen ranked third with 72 percent viability in Figure 4 and 60.70 percent in Figure 5. The free and encapsulated bromelain were evaluated by MTT assays using four different cell lines, which were HeLa, HEK293, MCF7 and A549, for 24, 48 and 72 hours, respectively [48]. It was found that the encapsulated bromelain needed significantly $(p<0.05)$ lower doses than the free bromelain alone. On the other hand, cells treated with the encapsulated bromelain did not show any significant decrease in cell viability. Despite some differences, such as in the cell line, period of time and treatments, the results were similar to the findings of this study [49]. In this study, the highest percentage of cell viability of HSF1184 inflamed by the $1.5 \mu \mathrm{g} / \mathrm{mL}$ LPS was achieved by the treated niosome-encapsulated bromelain compared to the non-encapsulated bromelain and the vehicle. The results of this study have shown that when the niosome alone acted as the vehicle, it did not affect the level of viable cells in the culture, thus suggesting that the anti-inflammatory effect of the niosome-encapsulated bromelain was not due to the presence of the vehicle [50]. The statistical analysis of the niosome-encapsulated $10 \%$ bromelain showed a significant difference in comparison with the other niosome treatments, where $P<0.05$.

\subsection{IL-6 and TNFa Response in LPS Induction of HSF1184 Treated with Niosome-Encapsulated Bromelain}

Interleukin-6 (IL-6) and tumour necrosis factor alpha (TNF- $\alpha$ ), the two immune-modulatory regulators of cell responses to inflammation, were measured in response to $1.5 \mu \mathrm{g} / \mathrm{mL}$ LPS-induced inflammation and were then treated with niosome-encapsulated bromelain, non-encapsulated bromelain, and the vehicle. The cytokines, IL- 6 and TNF- $\alpha$, were used because these pro-inflammatory cytokines play a key role in the inflammatory response and can be easily quantified in the supernatant.

\subsubsection{Determination of Inflammation Stage Using the IL-6 Response to Different Niosome Treatments:}

Interleukin-6 (IL-6) was measured in response to $1.5 \mu \mathrm{g} / \mathrm{mL}$ LPS and was then treated with niosome-encapsulated bromelain at a concentration of $20 \mu \mathrm{g} / \mathrm{mL}$, bromelain alone with a concentration of $25 \mu \mathrm{g} / \mathrm{mL}$, and niosome (vehicle) with a concentration of $20 \mu \mathrm{g} / \mathrm{mL} .1 \mathrm{~mL}$ DMEM was used as the blank sample and $1 \mathrm{~mL}$ of DMEM-plus cells was used as the control. All the concentrations resulted from previous experiments in this study. 


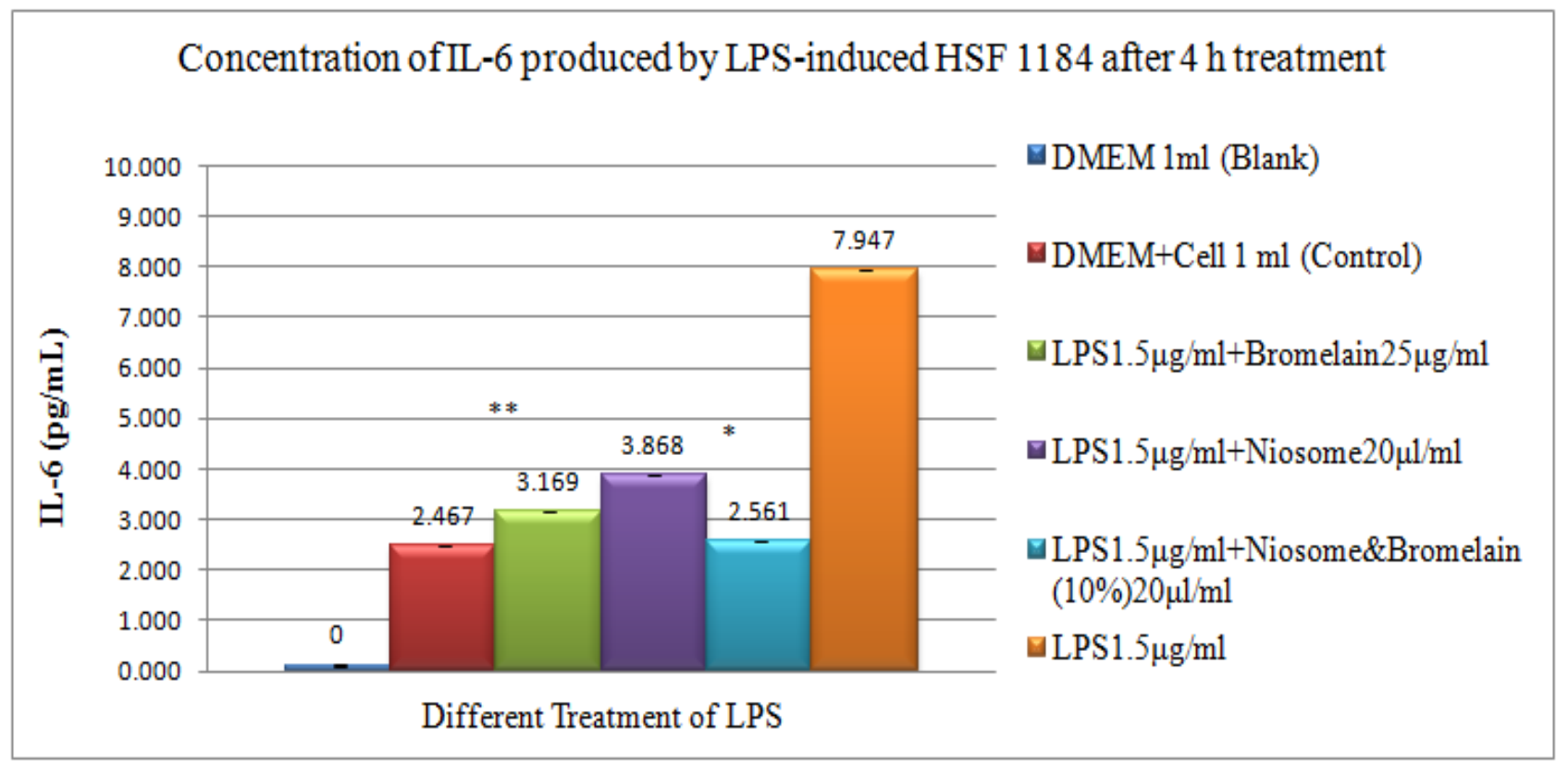

Figure 6. Concentration of IL-6 produced by LPS-induced HSF 1184 after 4 hrs.

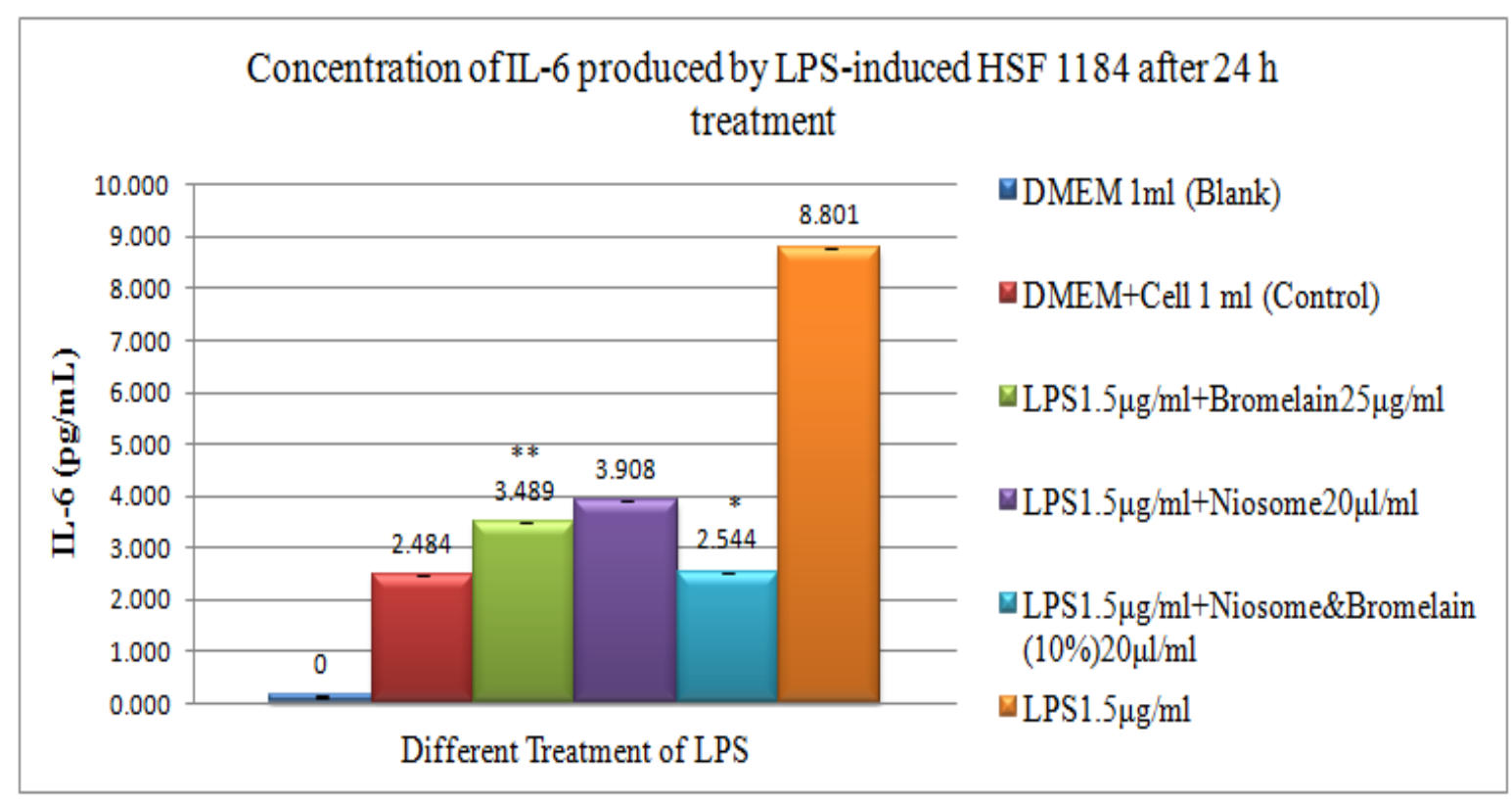

Figure 7. Concentration of IL-6 produced by LPS-induced HSF 1184 after 24 hrs.

Figure 6 and Figure 7 show that the lowest amounts of $2544 \mathrm{pg} / \mathrm{mL}$ in Figure 7 and $2561 \mathrm{pg} / \mathrm{mL}$ in Figure 6 belonged to the niosomeencapsulated bromelain. The highest amounts, marked at $3908 \mathrm{pg} / \mathrm{mL}$ in Figure 7 and $3868 \mathrm{pg} / \mathrm{mL}$ in Figure 6, were related to the vehicle. However, bromelain alone, reported at $3169 \mathrm{pg} / \mathrm{mL}$ in Figure 6 and 3489 $\mathrm{pg} / \mathrm{mL}$ in Figure 7 , was ranked second. Strong evidence on the antiinflammatory effect of theniosome-encapsulated $10 \%$ bromelain was found when the result of the quantitative cytokines concentration showed the highest induction for LPS without any treatment and vehicle. The lowest induction of inflammatory cytokines was observed in the niosomeencapsulated bromelain and the bromelain-treated cells, as previously mentioned by Mosmann (1983) [51]. The statistical analysis of the niosome-encapsulated $10 \%$ bromelain showed a significant difference compared to other treatments of niosome, where $P<0.05$.

\subsubsection{Determination of Inflammation Stage Using TNF-a Response to Different Niosome Treatments}

The tumour necrosis factor alpha (TNF- $\alpha$ ) was measured in response to $1.5 \mu \mathrm{g} / \mathrm{mL}$ LPS, and then to treatments with niosome-encapsulated bromelain at a concentration of $20 \mu \mathrm{g} / \mathrm{mL}$, bromelain alone at a concentration of $25 \mu \mathrm{g} / \mathrm{mL}$, and niosome (vehicle) at a concentration of $20 \mu \mathrm{g} / \mathrm{mL}$. The setup for the control and blank samples was similar to that of the IL-6. 


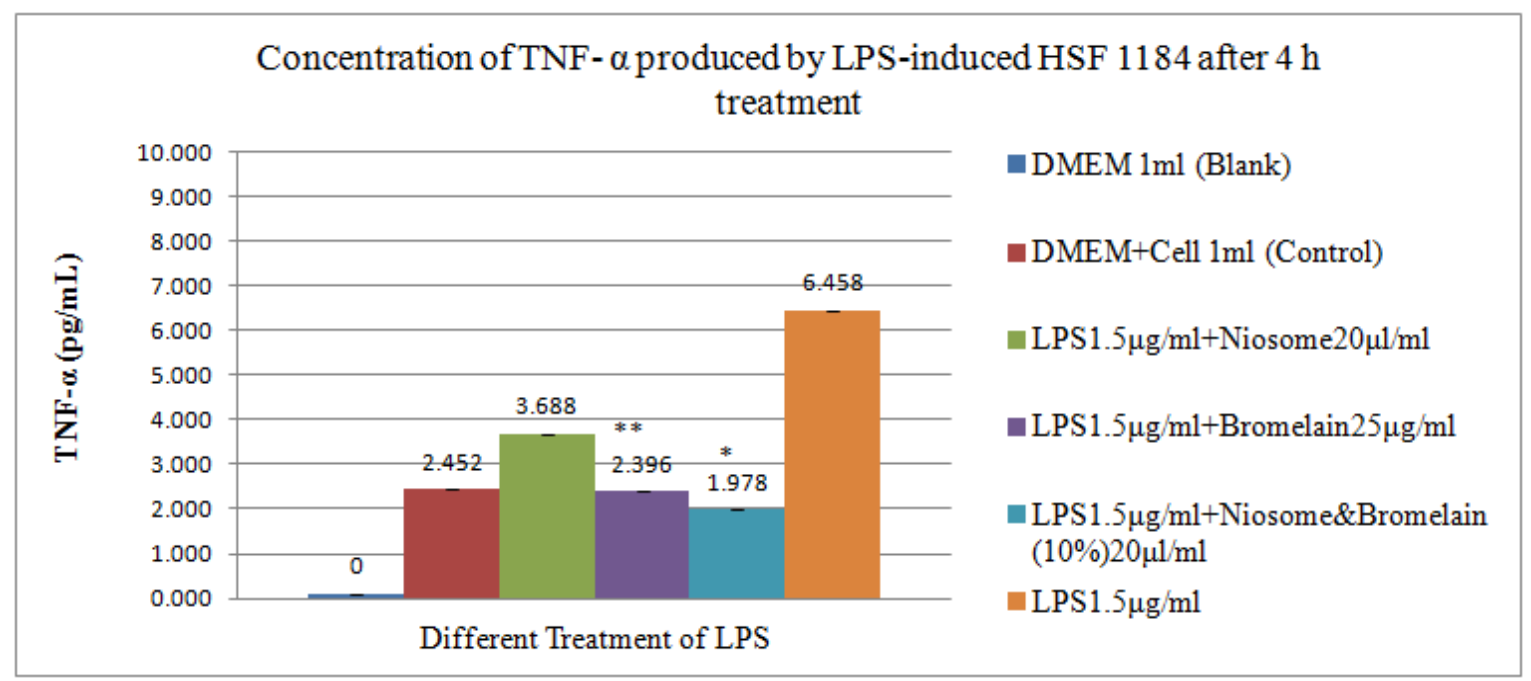

Figure 8. Concentration of TNF-aproduced by LPS-induced HSF 1184 after 4 hrs.

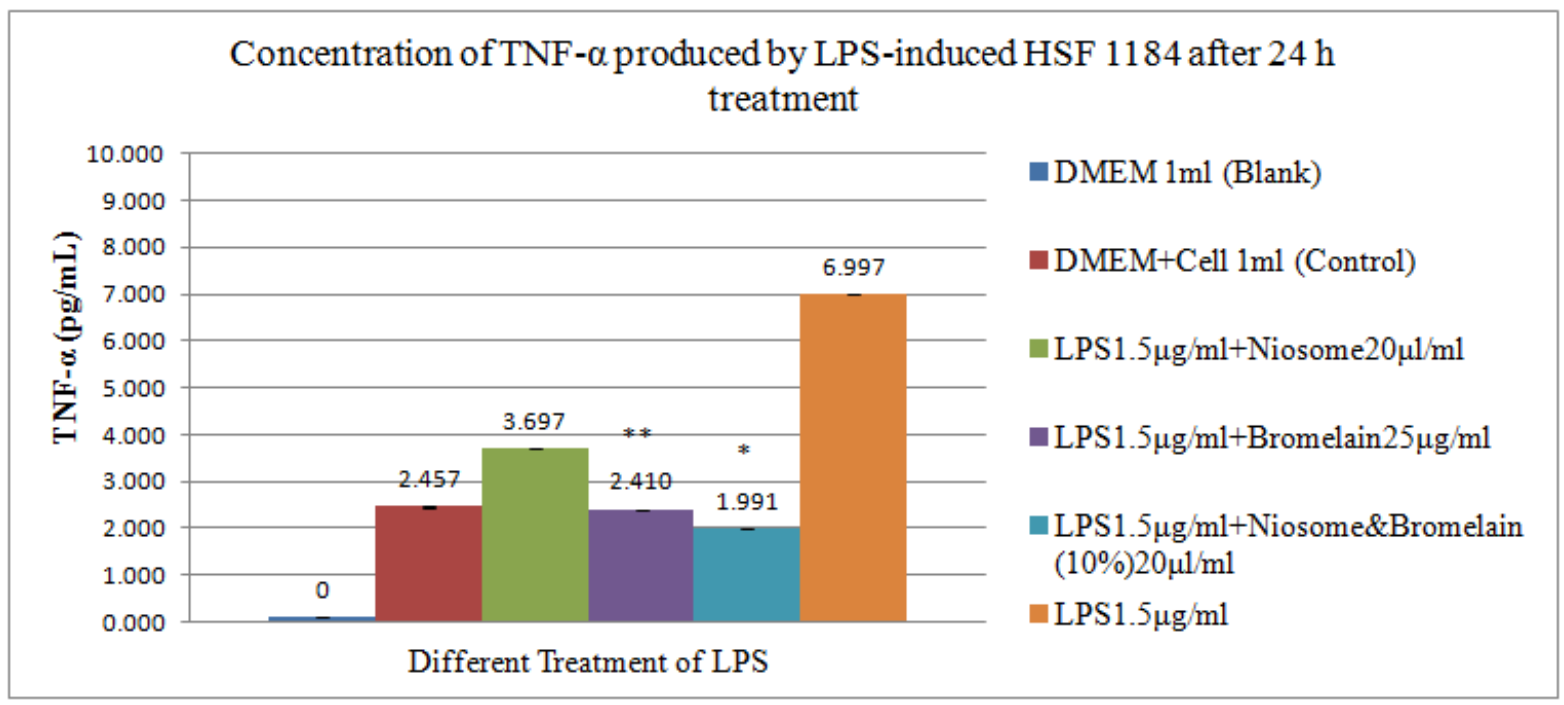

Figure 9. Concentration of TNF-aproduced by LPS-induced HSF 1184 after 24 hrs.

Figure 8 and Figure 9 show that the lowest amounts, marked at 1978 $\mathrm{pg} / \mathrm{mL}$ in Figure 8 and $1991 \mathrm{pg} / \mathrm{mL}$ in Figure 9, were from the niosomeencapsulated bromelain. The highest amounts, reported at $3697 \mathrm{pg} / \mathrm{mL}$ in Figure 9 and $3688 \mathrm{pg} / \mathrm{mL}$ in Figure 8, were related to the vehicle. However, bromelain alone was ranked second since the reported readings were $2396 \mathrm{pg} / \mathrm{mL}$ in Figure 8 and $2410 \mathrm{pg} / \mathrm{mL}$ in Figure 9.

Unlike IL-6, strong evidence on the anti-inflammatory effect of niosomeencapsulated $10 \%$ bromelain was from the low induction of inflammatory cytokines with the niosome-encapsulated $10 \%$ bromelain and bromelain. The highest induction was observed in the LPS without any treatment and the vehicle-treated cells (Mosmann, 1983) [51]. Again, the niosomeencapsulated $10 \%$ bromelain was statistically significant. The efficacy of the bromelain-niosome system on skin inflammation around the knee was evaluated. The potential anti-inflammatory properties of the niosomeencapsulated bromelain were investigated in the HSF1184 cell line because this model produces high concentrations of IL- 6 and TNF- $\alpha$ in cultures upon activation by LPS. Studies on the effects of bromelain on pro-inflammatory cytokines are limited. Moreover, no previous studies have evaluated the effects of niosome-encapsulated bromelain on IL-6 and TNF- $\alpha$ cytokines. Greenspan et al. (2005) [52] stimulated human endothelial cells with TNF- $\alpha$ and found that co-treatment with bromelain inhibited the production of TNF- $\alpha$ for LPS induction. However, in another study evaluating the inhibitory effects of bromelain on TNF- $\alpha$ production, Mastuda et al. (2012) [53] showed that bromelain inhibited the antigen IgE-mediated TNF- $\alpha$ secretion in RBL-2H3 mast cells. A potential reason for the differences in the results may be due to differences in the stimuli and cell types used. These findings are partly coherent with the results of this study, which show that niosome-encapsulated bromelain significantly impaired LPS-induced IL- 6 and TNF- $\alpha$ production. Apart from this finding, in different comparisons of niosome encapsulation, the niosomeencapsulated bromelain could be affected in a higher range compared to other treatments like bromelain alone or a vehicle. Moreover, the results showed that niosome alone as a vehicle did not affect the IL-6 and TNF$\alpha$ levels in the cultured supernatant and suggest that the immunostimulatory properties of the bromelain were not due to the presence of the vehicle [54]. On the other hand, during the post treatment, a pattern was observed where the anti-inflammatory cytokines peaked at four hours and 24 hours. A similar time period has been reported in numerous studies on humans [55]. Other key factors are the biological conditions of the HSF1184 cell line, for instance, inflammation induced by other components. Future perspectives should include an understanding on the molecular basis for the inhibitory effects of niosome-encapsulated bromelain on the HSF1184 cell line. The importance of niosome- 
encapsulated bromelain on the elimination of inflammation in the HSF1184 cell line infected by LPS-induced inflammation was evaluated. The result showed that niosome-encapsulated $10 \%$ bromelain significantly reduced the production of IL-6 and TNF- $\alpha$ in the LPSinduced human skin fibroblast cell line (HSF1184) after four hours post treatment as compared to the non-encapsulated bromelain and vehicle.

\section{Conclusion}

This study set out with the aim of assessing the importance of niosomeencapsulated bromelain in the elimination of inflammation in the HSF1184 cell line infected by LPS-induced inflammation. The results showed that niosome-encapsulated $10 \%$ bromelain significantly reduced the production of IL-6 and TNF- $\alpha$ in the LPS-induced human skin fibroblast cell line (HSF1184) after 4hours of post treatment as compared to the non-encapsulated bromelain and vehicle.

\section{References}

1. Mangesi, L. and Dowswell, T. (2010) Treatments for breast engorgement during lactation. Cochrane Database Syst Rev. 8(9).

2. Brien, S., Lewith, G., Walker, A., Middleton, R., Prescott, P. and Bundy, R. (2006). Bromelain as an adjunctive treatment for moderate-to-severe osteoarthritis of the knee: a randomized placebo-controlled pilot study. QJM. 99 (12): 841-850.

3. Klein, G., Kullich, W., Schnitker, J. and Schwann, H. (2006). Efficacy and tolerance of an oral enzyme combination in painful osteoarthritis of the hip.A double-blind, randomised study comparing oral enzymes with non-steroidal anti-inflammatory drugs. Clinical and experimental rheumatology. 24 (1): 25.

4. Guo, R., Canter, P. H. and Ernst, E. (2006). Herbal medicines for the treatment of rhinosinusitis: a systematic review. Otolaryngology-Head and Neck Surgery. 135 (4): 496-506.

5. Shahid, S., Turakhia, N., Kundra, M., Shanbag, P., Daftary, G. and Schiess, W. (2002). Efficacy and safety of Phlogenzym-A protease formulation, in sepsis in children.JAPI. 50: 527-531.

6. Lotti, T., Mirone, V., Imbimbo, C., Corrado, F., Corrado, G., Garofalo, F. and Scaricabarozzi, I. (1993). Controlled clinical studies of nimesulide in the treatment of urogenital inflammation. Drugs. 46 (1): 144-14

7. Maurer, H. R. (2001). Bromelain: biochemistry, pharmacology and medical use. Cellular and Molecular Life Sciences, 58(9), 1234-1245.

8. Madison, K. C. (2003). Barrier function of the skin: "La Raison d'Etre" of the epidermis. Journal of Investigative Dermatology, 121(2), 231-241.

9. Torchilin, V. P. (2005). Fluorescence microscopy to follow the targeting of liposomes and micelles to cells and their intracellular fate. Advanced Drug Delivery Reviews, 57(1), 95-109.

10. Farkas, E., Schubert, R., \& Zelko, R. (2004). Effect of betasitosterol on the characteristics of vesicular gels containing chlorhexidine. International Journal of Pharmaceutics, 278(1), 63-70.

11. Shen, C. Y., Rao, P. V., Batich, C. D., Moorhead, J., \& Yan, J. (1994). Stochastic Modeling of Controlled-Release from PolyStyrene-Co-4-Vinylpyridine Microspheres. Journal of Controlled Release, 32(2), 139-146.

12. Mozafari, R. M. (2005). Nanoliposomes: from Fundamentals to Recent Developments: Oxford, UK. Trafford Pub.Ltd.

13. Kogan, A., \& Garti, N. (2006). Microemulsions as transdermal drug delivery vehicles. Advances in Colloid and Interface Science, 123-126(0), 369-385.

14. Patel, G. B., Omri, A., Deschatelets, L., \& Dennis Sprott, G. (2002). Safety of archaeosome adjuvants evaluated in a mouse model 1*. Journal of Liposome Research, 12(4), 353-372.
15. Ravi Kumar, M., Bakowsky, U., \& Lehr, C. (2004). Preparation and characterization of cationic PLGA nanospheres as DNA carriers. Biomaterials, 25(10), 1771-1777.

16. Teixeira, M., Alonso, M. J., Pinto, M. M. M., \& Barbosa, C. M. (2005). Development and characterization of PLGA nanospheres and nanocapsules containing xanthone and 3-methoxyxanthone. European Journal of Pharmaceutics and Biopharmaceutics, 59(3), 491-500.

17. Escobar-Chávez, J.J., Rodríguez-Cruz, I.M., DomínguezDelgado, C.L., Díaz- Torres,R. Revilla-Vázquez,A.L., Aléncaster, N.C. (2012). Nanocarrier Systems for Transdermal Drug Delivery.Recent Advances in Novel Drug Carrier Systems: 51(8), 978-953.

18. Chobotova, K., Vernallis, A. B. and Majid, F. A. A. (2010). Bromelain's activity and potential as an anti-cancer agent: current evidence and perspectives. Cancer letters. 290 (2): 148-156.

19. Palozza, P., Muzzalupo, R., Trombino, S., Valdannini, A., \& Picci, N. (2006). Solubilization and stabilization of beta-carotene in niosomes: delivery to cultured cells. Chemistry and Physics of Lipids, 139(1), 32-42.

20. Brouckaert, P., Libert, C., Everaerdt, B., Takahashi, N., Cauwels, A. and Fiers, W. (1993). Tumor necrosis factor, its receptors and the connection with interleukin 1 and interleukin 6.Immunobiology. 187 (3): 317-329.

21. Alsarra, I. A., Bosela, A., Ahmed, S., \& Mahrous, G. (2005). Proniosomes as a drug carrier for transdermal delivery of ketorolac. European Journal of Pharmaceutics and Biopharmaceutics, 59(3), 485-490.

22. Manconi, M., Sinico, C., Valenti, D., Lai, F., \& Fadda, A. M. (2006). Niosomes as carriers for tretinoin III. A study into the in vitro cutaneous delivery of vesicle-incorporated tretinoin. International Journal of Pharmaceutics, 311(1-2), 11-19.

23. Poltorak A et al.; He, X; Smirnova, I; Liu, MY; Van Huffel, C; $\mathrm{Du}, \mathrm{X}$; Birdwell, D; Alejos, E et al. (1998). Defective LPS Signaling in $\mathrm{C} 3 \mathrm{H} / \mathrm{HeJ}$ and $\mathrm{C} 57 \mathrm{BL} / 10 \mathrm{ScCr}$ Mice: Mutations in Tlr4 Gene. Science 282 (5396): 2085-2088.

24. Huang, J.-R., Wu, C.-C., Hou, R. C.-W. andJeng, K.-C. (2008). Bromelain inhibits lipopolysaccharide-induced cytokine production in human THP-1 monocytes via the removal of CD14. Immunological investigations. 37 (4): 263-277.

25. Hou, R. C.-W., Chen, Y.-S., Huang, J.-R. andJeng, K.-C. G. (2006) Cross-linked bromelain inhibits lipopolysaccharideinduced cytokine production involving cellular signaling suppression in rats. Journal of agricultural and food chemistry. 54 (6): 2193-2198.

26. Balkwill, F. C., K.A., \&Mantovani, A (2005). Smoldering and polarized inflammation in the initiation and promotion of malignant disease. Cancer Cell 7(3): 211-217.

27. Yoshimura, A. (2006). Signal transduction of inflammatory cytokines and tumor development. Cancer science. 97 (6): 439447.

28. Qin, Z. and Blankenstein, T. (2000). CD4+ T Cell-Mediated Tumor Rejection Involves Inhibition of Angiogenesis that Is Dependent on IFN $\gamma$ Receptor Expression by Nonhematopoietic Cells. Immunity. 12 (6): 677-686.

29. Heuschkel, S., Goebel, A. and Neubert, R. H. (2008). Microemulsions-modern colloidal carrier for dermal and transdermal drug delivery.Journal of pharmaceutical sciences. 97 (2): 603-631.

30. Desser, L., Rehberger, A., Kokron, E. and Paukovits, W. (1993). Cytokine synthesis in human peripheral blood mononuclear cells after oral administration of polyenzyme preparations.Oncology. 50 (6): 403-407. 
31. Desser, L., Rehberger, A. and Paukovits, W. (1994). Proteolytic enzymes and amylase induce cytokine production in human peripheral blood mononuclear cells in vitro. Cancer Biotherapy \& Radiopharmaceuticals. 9 (3): 253-263.

32. Barth, H., Guseo, A. and Klein, R. (2005). In vitro study on the immunological effect of bromelain and trypsin on mononuclear cells from humans. European journal of medical research. 10 (8): 325-331.

33. Engwerda, C. R., Andrew, D., Murphy, M. and Mynott, T. L. (2001). Bromelain Activates Murine Macrophages and Natural Killer Cells in vitro.Cellular immunology. 210 (1): 5-10.

34. Onken, J. E., Greer, P. K., Calingaert, B. and Hale, L. P. (2008). Bromelain treatment decreases secretion of pro-inflammatory cytokines and chemokines by colon biopsies in vitro. Clinical Immunology. 126 (3): 345-352.

35. Bauer, J. and Herrmann, F. (1991). Interleukin-6 in clinical medicine.Annals of hematology. 62 (6): 203-210.

36. Shiew, P. S., Fang, Y. L. and Majid, F. A. A. (2010). In vitro study of bromelain activity inartificial stomach juiceand blood. Paper presented at the 3rd International Conference on Biotechnology for the Wellness Industry, PWTC Kuala Lumpur.

37. Cannon, J. G. (2000). Inflammatory cytokines in nonpathological states.Physiology, 15(6), 298-303.

38. Bhatnagar, P. and Gupta, K. Ch. (2013). Oral Administration of Eudragit Coated Bromelain encapsulated PLGA Nanoparticles for Effective Delivery of Bromelain for Chemotherapy in vivo.29th Southern Biomedical Engineering Conference.

39. Hamishehkar, H.,Rahimpour, Y., Kouhsoltani, M.(2013). Niosomes as a propitiouscarrier for topical drug delivery.Expert Opin.Drug Deliv. 10, 261-272.

40. Bouwstra, J. A., van Hal, D. A., Hofland, H. E., \& Junginger, H. E. (1996). Preparation and characterization of nonionic surfactant vesicles. Colloids and Surfaces A: Physicochemical and Engineering Aspects, 123, 71-80.

41. Kato, K., Walde, P., Koine, N., Ichikawa, S., Ishikawa, Tet al. (2008). Temperature-sensitivenonionic vesicles prepared from Span 80 (sorbitanmonooleate). Langmuir. 24,10762-10770.

42. Cesar, A. C. W. (2005). Economic Feasibility Analysis of a Case of Extraction and Purification of Bromelain Pineapple. Unicamp, School of Chemical Engineering.

43. Boyle, J. (2005). Macrophage activation in atherosclerosis: pathogenesis and pharmacology of plaque rupture. Current vascular pharmacology, 3(1), 63-68.
44. Arora, R., Sharma A (2010). Release studies of ketoprofenniosome formulation. Journal of Chemical and Pharmaceutical Research. 2: 79-82.

45. Freshney B. C. (2008). Transdermal drug delivery-What to expect in the near future. Business briefing: Pharma tech, 192-193.

46. Zdařilová, A., Svobodová, A., Šimánek, V. and Ulrichová, J. (2009). Prunella Vulgaris Extract and Rosmarinic acid Suppress lipopolysaccharide-induced alteration in human gingival fibroblasts. Toxicology in vitro. 23 (3): 386-392.

47. Gude, R., Jadhav, M., Rao, S., \& Jagtap, A. (2002). Effects of niosomal cisplatin and combination of the same with theophylline and with activated macrophages in murine B16F10 melanoma model. Cancer biotherapy and radiopharmaceuticals,

48. Mu, L., Elbayoumi, T., \& Torchilin, V. (2005). Mixed micelles made of poly (ethylene glycol)-phosphatidylethanolamine conjugate and d- $\alpha$-tocopheryl polyethylene glycol 1000 succinate as pharmaceutical nanocarriers for camptothecin. International journal of pharmaceutics, 306(1), 142-149.

49. Hood, E. D. (2007). Antibody Targeting of Non Ionic Surfactant Vesicles to Vascular Inflammation. University of South Florida, Tampa, Florida, USA.

50. Marieb, E. N. (2007). Essentials of Human Anatomy and Physiology. California: Benjamin/Cummings Publishing Company.

51. Mosmann, T. (1983). Rapid colorimetric assay for cellular growth and survival: application to proliferation and cytotoxicity assays. Journal of immunological methods. 65 (1): 55-63.

52. Greenspan, P., \& Fowler, S. D. (2005). Spectrofluorometric studies of the lipid probe, nile red. Journal of lipid research, 26(7), 781-789.

53. Mastuda, H., Morikawa, T., Ueda, K., Managi, H., Yoshikawa, M. (2012). Structural requirements of flavonoids for inhibition of antigen-induced degranulation, TNF-alpha and IL-4 production from RBL-2H3 cells. Bioorganic and Medicinal Chemistry, 10, 3123-3128.

54. Kalra, N., Bhui, K., Roy, P., Srivastava, S., George, J., Prasad, S., et al. (2008). Regulation of p53, nuclear factor $\kappa B$ and cyclooxygenase- 2 expression by bromelain through targeting mitogen-activated protein kinase pathway in mouse skin. Toxicology and applied pharmacology, 226(1), 30-37.

55. Hosoya, K.-i., Takashima, T., Matsuda, K.-i., \& Terasaki, T. (2002). Spleen lymphocyte kinetics in mice under normal and inflammatory conditions: an application of the transgenic mouse expressing beta-galactosidase (ROSA 26). Biological and pharmaceutical bulletin, 25(10), 1378-1380.

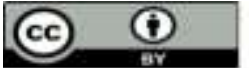

This work is licensed under Creative Commons Attribution 4.0 License

To Submit Your Article Click Here: Submit Manuscript

DOI: $10.31579 / 2766-2314 / 044$
Ready to submit your research? Choose Auctores and benefit from:

* fast, convenient online submission

* rigorous peer review by experienced research in your field

* rapid publication on acceptance

* authors retain copyrights

* unique DOI for all articles

* immediate, unrestricted online access

At Auctores, research is always in progress.

Learn more https://auctoresonline.org/journals/biotechnology-andbioprocessing 